\title{
Risk Assessment Tools for Categorisation of Failure Modes of Marine Diesel Engine: A Comparative StUdY
}

\author{
Ikuobase EMOVON*, Modestus Okechukwu OKWU \\ Department of Mechanical Engineering, Federal University of Petroleum Resources, \\ P.M.B. 1221, Effurun, Delta State, Nigeria \\ *Corresponding Author: Ikuobase EMOVON (email: emovon.ikuobase@fupre.edu.ng) \\ (Received: 05-November-2017; accepted: 26-December-2017; published: 31-March-2018) \\ DOI: http://dx.doi.org/10.25073/jaec.201821.80
}

\begin{abstract}
Risk assessment is a vital element of most maintenance system, this is because safeguarding of equipment item requires maintenance strategies which usually depend on the degree of risk of the equipment item. In this paper two risk assessment tools; Risk Priority Number (RPN) based approach and Risk Matrix (RM) based approach, are presented for categorisation of risk of failure modes of marine diesel engine. The techniques are used to categorise failure modes into three risk levels; low, medium and high in turn and based on the risk level, maintenance strategy are assigned to each failure modes. Furthermore, the two techniques are compared and the result of the analysis revealed that, the extent of Risk matrix method similarity to the RPN approach depends on the benchmark for setting the risk level limit in the RPN method.
\end{abstract}

KeyWords: Risk assessment, Marine diesel engine, Risk categorisation, Risk level, Maintenance strategy.

\section{Introduction}

British Standard define maintenance as 1 "the combination of all technical and administrative actions, intended to retain an item in, or restore it to a state in which it can perform a re- quired action". There are basically three types of maintenance namely; corrective, preventive and condition based maintenance. However, Marine machinery systems are composed of many equipment items and each of these equipment items possess different level of risk to the system. The degree of risk each equipment item possesses will determine the level of maintenance consideration, necessary for optimal system safety and reliability [2] at minimum cost. A mix of different maintenance strategies is therefore required for the maintenance of marine machinery system. The major challenge is how to determine which strategy is appropriate for a particular equipment item. In the use of risk as the basis for selecting appropriate maintenance strategy, the risk contribution of each equipment to the overall system is evaluated and then categorised using appropriate risk assessment techniques. The equipment items with high risk are generally tagged for Condition Based Maintenance $(\mathrm{CBM})$ while equipment with low risk are labelled for Corrective Maintenance (CM).

Risk is defined as the combination of probability of failure of an equipment of a system and the resulting consequence due to the failure [2]. Three categories of risk assessment techniques are identified in the literature namely; qualitative, semi quantitative and quantitative [3]. The commonly use method is the semi quantitative 
and one variant of it, is the risk matrix technique [3].

The risk matrix technique had been applied by different authors in prioritizing risk of failures modes of equipment items in diverse field. Nordgard and Samdal [4] used the approach to determine the risk of failure contribution of the different components of electricity distribution system in order to establish the appropriate mix of maintenance strategies for the maintenance management of the system. Nwaoha et al., 5] applied the technique to prioritize the various LNG carrier operations hazards. Haifang, et al., [6] utilized the approach to prioritize the risk of factors associated with the management of government project using private funds. Lazakis [7] used the approach to categories risk of failure of an equipment of a ship system into four level of criticality namely; low, moderate, significant and high criticality.

Another variant of the risk assessment tool, is the RPN use within the framework of Failure Mode and Effect Analysis (FMEA). In this approach, risk is evaluated as the product of failure probability $(\mathrm{O})$, the resulting consequences due to the failure $(\mathrm{S})$ and the possibility of detecting the failure before it occurs (D). The use of this approach requires another technique such as ALARP (As Low As Reasonable Practicable) to set failure modes RPN values into different level of risk 8 .

The RPN risk assessment methodology had been applied by different authors in the literature to categorise failure modes into different risk level. Santos et al., [8] used the RPN based approach to categorise risk of failures of different equipment items of an air conditioned chiller system of a vessel into acceptable, tolerable and unacceptable risk. Firstly the RPN of the various failure modes of the system were evaluated. The authors then use ALARP technique to categories the risk of failure modes into three groups; those scoring equal to or greater than $70 \%$ of the maximum RPN value belonging to the un-acceptable risk group, those scoring between $40 \%$ and $70 \%$ of the maximum RPN value belonging to the tolerable risk group and those scoring equal to or less than $40 \%$ of the maximum RPN value belonging to the acceptable risk group. Jamshidi et al., 9] applied Fuzzy RPN whilst considering several factors to evaluate risk contribution of various medical devices. The medical devices were then categorize into four risk levels; low priority, second low priority, high priority and very high priority. The authors proposed; corrective maintenance, preventive maintenance, condition based maintenance and preventive or condition based maintenance to the four risk levels respectively.

From the above literature survey, it is obvious, different authors had applied either risk matrix or RPN based methodologies individually as a tool for the categorization of risk of failure modes into three or more levels of risk and matched appropriate maintenance strategy for each risk level. However, in this paper the two risk assessment tool is utilized in the categorization of failure modes of marine diesel engine; a marine machinery system. Additionally, the two techniques are compared in an unbiased manner by applying a 10 point scale for both techniques as opposed to the use of 4 or 5 point scale in the literature for the risk matrix technique, in order to effectively determine their similarity and their effect in maintenance strategy selection.

\section{Methodology}

\subsection{Risk Assessment: Risk Priority Number (RPN) Approach}

Risk assessment in the context of this paper consist of two components; Risk estimation and risk categorisation. Both components of the risk assessment is be evaluated with the use of RPN based approach.

\subsubsection{Risk estimation}

As earlier stated, RPN is expressed as the product of failure probability $(\mathrm{O})$, the consequence resulting from the failure (S) and the possibility of detecting the failure (D). This is represented mathematically as follows:

$$
R P N=O \times S \times D
$$


The tool is applied within the framework of FMEA for prioritising the failure modes of industrial systems which include the marine machinery systems. FMEA is a systematic technique for identifying failure modes of equipment items of a system, failure causes and effect of the failure in order to mitigate the effect of the failure. The origin of the FMEA is dated back to 1947 when it was developed by the United States Army and in the 1970s, the use of the technique was extended to the aviation and the automotive industries [10. Nowadays, the technique and its variant had become a popular tool in most industries; marine industries inclusive for evaluating risk of failure modes [11].

To evaluate RPN, values are assign to $\mathrm{O}, \mathrm{S}$ and $\mathrm{D}$ by experts for each failure modes using a 10 point scale shown in Tab. 1-3 respectively.

Tab. 1: Failure probability rating 12$] 13$.

\begin{tabular}{|c|c|c|}
\hline Rating & $\begin{array}{l}\text { Probability of } \\
\text { failure }\end{array}$ & $\begin{array}{l}\text { Possible failure } \\
\text { rate }\end{array}$ \\
\hline 10 & $\begin{array}{l}\text { Very high: fail- } \\
\text { ure is almost } \\
\text { inevitable }\end{array}$ & $>1 / 2$ \\
\hline 9 & & $1 / 3$ \\
\hline 8 & $\begin{array}{l}\text { High: repeated } \\
\text { failures }\end{array}$ & $1 / 8$ \\
\hline 7 & & $1 / 20$ \\
\hline 6 & $\begin{array}{l}\text { Moderate: } \\
\text { occasional } \\
\text { failures }\end{array}$ & $1 / 80$ \\
\hline 5 & & $1 / 400$ \\
\hline 4 & & $1 / 2000$ \\
\hline 3 & $\begin{array}{lr}\text { Low: } & \text { rela- } \\
\text { tively } & \text { few } \\
\text { failures } & \end{array}$ & $1 / 15000$ \\
\hline 2 & & $1 / 150000$ \\
\hline 1 & $\begin{array}{l}\text { Remote: fail- } \\
\text { ure is unlikely }\end{array}$ & $<1 / 1500000$ \\
\hline
\end{tabular}

Tab. 2: Consequences of failure rating [13].

\begin{tabular}{|c|c|c|}
\hline Rating & Effect & Severity of effect \\
\hline 10 & $\begin{array}{l}\text { Hazardous } \\
\text { without } \\
\text { warning }\end{array}$ & $\begin{array}{l}\text { Engine failure } \\
\text { resulting in haz- } \\
\text { ardous effects } \\
\text { almost certain }\end{array}$ \\
\hline 9 & $\begin{array}{l}\text { Hazardous } \\
\text { with warn- } \\
\text { ing }\end{array}$ & $\begin{array}{l}\text { Engine failure } \\
\text { resulting in haz- } \\
\text { ardous effects } \\
\text { highly probable }\end{array}$ \\
\hline 8 & Very high & $\begin{array}{l}\text { Engine inopera- } \\
\text { ble but safe }\end{array}$ \\
\hline 7 & High & $\begin{array}{l}\text { Engine perfor- } \\
\text { mance severely } \\
\text { affected }\end{array}$ \\
\hline 6 & Moderate & $\begin{array}{l}\text { Engine operable } \\
\text { and safe but } \\
\text { performance } \\
\text { degraded }\end{array}$ \\
\hline 5 & Low & $\begin{array}{l}\text { Reduced per- } \\
\text { formance with } \\
\text { gradual perfor- } \\
\text { mance degrada- } \\
\text { tion }\end{array}$ \\
\hline 4 & Very low & $\begin{array}{l}\text { Minor effect on } \\
\text { product perfor- } \\
\text { mance }\end{array}$ \\
\hline 3 & Minor & $\begin{array}{l}\text { Slight effect on } \\
\text { product perfor- } \\
\text { mance. Non- } \\
\text { vital faults will } \\
\text { be noticed most } \\
\text { of the time }\end{array}$ \\
\hline 2 & Very minor & $\begin{array}{l}\text { Negligible effect } \\
\text { on product per- } \\
\text { formance }\end{array}$ \\
\hline 1 & None & No effect \\
\hline
\end{tabular}


Tab. 3: Detectability rating $12,13,14,15$

\begin{tabular}{|c|c|c|}
\hline Rating & Detection & Criteria \\
\hline 10 & $\begin{array}{l}\text { Absolutely } \\
\text { impossi- } \\
\text { ble }\end{array}$ & $\begin{array}{l}\text { Control system } \\
\text { will not and /or } \\
\text { cannot detect a } \\
\text { potential cause } \\
\text { and subsequent } \\
\text { failure mode or } \\
\text { there is no design } \\
\text { control }\end{array}$ \\
\hline 9 & $\begin{array}{l}\text { Very } \\
\text { remote }\end{array}$ & $\begin{array}{l}\text { Very remote } \\
\text { change the control } \\
\text { system will detect } \\
\text { a potential cause } \\
\text { and subsequent } \\
\text { failure mode }\end{array}$ \\
\hline 8 & Remote & $\begin{array}{l}\text { Remote change } \\
\text { the control sys- } \\
\text { tem will detect } \\
\text { a potential cause } \\
\text { and subsequent } \\
\text { failure mode }\end{array}$ \\
\hline 7 & Very low & $\begin{array}{l}\text { Very low change } \\
\text { the control system } \\
\text { will detect a po- } \\
\text { tential cause and } \\
\text { subsequent failure } \\
\text { mode }\end{array}$ \\
\hline 6 & Low & $\begin{array}{l}\text { Low change the } \\
\text { control system } \\
\text { will detect a po- } \\
\text { tential cause and } \\
\text { subsequent failure } \\
\text { mode }\end{array}$ \\
\hline 5 & Moderate & $\begin{array}{l}\text { Moderate change } \\
\text { the control system } \\
\text { will detect a po- } \\
\text { tential cause and } \\
\text { subsequent failure } \\
\text { mode }\end{array}$ \\
\hline
\end{tabular}

\begin{tabular}{|l|l|l|}
\hline 4 & $\begin{array}{l}\text { Moderately } \\
\text { high }\end{array}$ & $\begin{array}{l}\text { Moderately high } \\
\text { change the control } \\
\text { system will detect } \\
\text { a potential cause } \\
\text { and subsequent } \\
\text { failure mode }\end{array}$ \\
\hline 3 & High & $\begin{array}{l}\text { High change the } \\
\text { control system } \\
\text { will detect a po- } \\
\text { tential cause and } \\
\text { subsequent failure } \\
\text { mode }\end{array}$ \\
\hline 2 & Very high & $\begin{array}{l}\text { Very high change } \\
\text { the control system } \\
\text { will detect a po- } \\
\text { tential cause and } \\
\text { subsequent failure } \\
\text { mode }\end{array}$ \\
\hline 1 & $\begin{array}{l}\text { Almost } \\
\text { certain }\end{array}$ & $\begin{array}{l}\text { Control system } \\
\text { will almost cer- } \\
\text { tainly detect a } \\
\text { potential cause } \\
\text { and subsequent } \\
\text { failure mode }\end{array}$ \\
\hline
\end{tabular}

\subsubsection{Risk Categorisation}

To categorise risk of failure modes of the system into 3 or more risk level, experts or the decision makers can utilise a certain \% of the maximum risk possible to define the risk level limit [8]. For example, Santos et al [8] opined that failure modes with RPN score equal or greater than $70 \%$ of the maximum risk possible, belong to the "non-acceptable" risk group while failure modes with an RPN score between $40 \%$ and 70 $\%$ and RPN score below $40 \%$ of the maximum risk possibly belong to the tolerable risk group and acceptable risk group respectively. In this paper, Santos et al. [8] approach is used to categorise risk of failure modes of marine diesel engine into three risk level; low, medium and high risks. However, three set of indexes were utilised to defined risk level, in this paper as oppose to one index used by Santos et al., [8] and are shown in Tab. 4 . 
Tab. 4: Level of risk indexes.

\begin{tabular}{|l|l|}
\hline RPN index 1 & Level of risk \\
\hline$<10 \%$ & Low \\
\hline $10 \% \leq \mathrm{RPN} \leq 30 \%$ & Medium \\
\hline$\geq 30 \%$ & High \\
\hline $\mathbf{R P N}$ index $\mathbf{2}$ & Level of risk \\
\hline$<20 \%$ & Low \\
\hline $20 \% \leq \mathrm{RPN} \leq 50 \%$ & Medium \\
\hline$\geq 50 \%$ & High \\
\hline $\mathbf{R P N}$ index $\mathbf{3}$ & Level of risk \\
\hline$<40 \%$ & Low \\
\hline $40 \% \leq \mathrm{RPN} \leq 70 \%$ & Medium \\
\hline$\geq 70 \%$ & High \\
\hline
\end{tabular}

Having categorise failure modes into different risk level, the next step is to assign appropriate maintenance strategy to each failure mode based on their individual risk level. Jamshidi et al., 9 assigned, CM, PM, CBM and PM or CBM to medical devices rated; low priority with very low risk index score, low priority, high priority and very high priority respectively.

In this paper, a similar approach will be followed, to assign maintenance strategy to failure modes of marine diesel engine based on their individual risk level. The low risk failure modes equipment items will be candidates for $\mathrm{CM}$ while the medium and high risk failure modes equipment items will be candidates for PM and CBM respectively.

\subsection{Risk Assessment: Risk matrix approach}

The two components of risk assessment; risk estimation and risk categorisation in this paper's perspective can also be evaluated with a technique, which we identified as Risk matrix based approach.

\subsubsection{Risk estimation}

Risk is the product of probability of failure and the consequences of the failure [16]. Based on this definition, risk is quantified by estimating the probability of failure $(\mathrm{O})$ and the consequences of the failure $(\mathrm{S})$ as opposed to the use of three factors; O, S and D for estimating risk in the RPN based approach.

In estimating risk, from this perspective, quantitative or qualitative risk assessment technique can be applied. In the qualitative technique, the use of a pre-determine scale, examples shown in Tab. 1 and Tab. 2 are applied in the rating of $\mathrm{O}$ and $\mathrm{S}$. The scale is generally defined and administered by experts based on their own opinions. However, the approach is generally suitable when reliable data are not available for risk estimation and when the risk of failure of the system are mild and well known. The ratings of $\mathrm{O}$ and $\mathrm{S}$ of the different failure modes of the marine diesel engine by experts is the first step in the Risk matrix based methodology.

\subsubsection{Risk categorisation}

Having rated $\mathrm{O}$ and $\mathrm{S}$ of each failure modes of the system, with the scale in Tab.1 1 and Tab. 2 the risk of failure modes are then categorised into different risk levels using a matrix of $\mathrm{O}$ and $\mathrm{S}$. There are variant risk matrix various authors have applied in the literature for the categorisation of risk of failure modes into diverse risk level. Three examples, of risk matrix are presented in Tab. 5 Tab. 6 and Tab. 7

Tab. 5: Hammed and Khan [17] risk matrix.

\begin{tabular}{|l|l|l|l|l|l|}
\cline { 2 - 6 } \multicolumn{1}{c|}{} & \multicolumn{5}{c|}{$S$ rating } \\
\hline O rating & 1 & 2 & 3 & 4 & 5 \\
\hline 5 & & & & & \\
\hline 4 & & & & & \\
\hline 3 & & & & & \\
\hline 2 & & & & & \\
\hline 1 & & & & & \\
\hline
\end{tabular}


Tab. 6: Nordgard and Samdal 4] risk matrix.

\begin{tabular}{|l|l|l|l|l|l|}
\cline { 2 - 6 } \multicolumn{1}{c|}{} & \multicolumn{5}{c|}{$S$ rating } \\
\hline$O$ rating & 1 & 2 & 3 & 4 & 5 \\
\hline 5 & & & & & \\
\hline 4 & & & & & \\
\hline 3 & & & & & \\
\hline 2 & & & & & \\
\hline 1 & & & & & \\
\hline
\end{tabular}

Tab. 7: lazakis [7 risk matrix.

\begin{tabular}{|l|l|l|l|l|l|}
\cline { 2 - 6 } \multicolumn{1}{c|}{} & \multicolumn{5}{c|}{$S$ rating } \\
\hline O rating & 1 & 2 & 3 & 4 & 5 \\
\hline 5 & & & & & \\
\hline 4 & & & & & \\
\hline 3 & & & & & \\
\hline 2 & & & & & \\
\hline 1 & & & & & \\
\hline
\end{tabular}

In Tab. 5.77, a 5 point scale were used by the authors to developed $\mathrm{O}$ and $\mathrm{S}$ matrix. Tab. 5 and Tab. 6 consist of three risk levels; green, yellow, red areas representing low, medium and high risk respectively while Tab. 7 consist of four risk levels ; green , yellow, purple and red areas representing low, moderate, significant and high risks respectively.

From the above, different risk matrix have been developed and applied by different authors for the categorisation of risk of failure modes. Although, the risk matrix presented above utilises five point scale, in this paper a 10 point scale is applied to develop a risk matrix based on Nordgard and Samdal 4 risk matrix and the developed matrix is shown in Tab. 8. The risk matrix is composed of three risk levels; the green, yellow and the red areas representing low, medium and high risks respectively as presented in Tab. 9 .
Tab. 8: Risk matrix

\begin{tabular}{|l|l|l|l|l|l|l|l|l|l|l|}
\cline { 2 - 9 } \multicolumn{1}{c|}{} & \multicolumn{10}{|c|}{$S$ rating } \\
\hline $\begin{array}{l}O \\
\text { rating }\end{array}$ & 1 & 2 & 3 & 4 & 5 & 6 & 7 & 8 & 9 & 10 \\
\hline 10 & & & & & & & & & & \\
\hline 9 & & & & & & & & & & \\
\hline 8 & & & & & & & & & & \\
\hline 7 & & & & & & & & & & \\
\hline 6 & & & & & & & & & & \\
\hline 5 & & & & & & & & & & \\
\hline 4 & & & & & & & & & & \\
\hline 3 & & & & & & & & & & \\
\hline 2 & & & & & & & & & & \\
\hline 1 & & & & & & & & & & \\
\hline
\end{tabular}

Tab. 9: Risk matrix index.

\begin{tabular}{|l|l|}
\hline Matrix area & Levels of risk \\
\hline Green & Low \\
\hline yellow & Medium \\
\hline Red & High \\
\hline
\end{tabular}

To apply the risk matrix, in categorising risk of failure modes, each failure mode $\mathrm{O}$ and $\mathrm{S}$ ratings is match with the risk matrix. For example, if a particular failure mode is assign $\mathrm{O}$ rating of 8 and assign $\mathrm{S}$ rating of 7 . In the risk matrix in Tab. 8 move to $\mathrm{O}$ rating position 8 and check where it intercept with $\mathrm{S}$ rating position 7 . The interception point is within the red area, meaning the failure mode risk is high.

The low risk failure modes equipment will be candidates for $\mathrm{CM}$ while the medium and high risks failure modes will be candidate for PM and CM respectively.

\section{Data collection and analysis}

To illustrate the applicability of the two methods, for risk assessment of failure modes, a marine diesel engine was considered as a case study. The example had earlier been applied by Emovon et al. [18 to demonstrate the use of Multi-Criteria Decision Making (MCDM) enhanced FMEA in prioritising risk of failure 
modes. The equipment items considered include among others; main bearing, cylinder head and crankshaft and 23 failure modes were identified from the equipment items. For each failure modes, three experts assigned ratings for the risk factors; $\mathrm{O}, \mathrm{S}$ and $\mathrm{D}$ using the pre-determined scale in Tab. 1. Tab. 2 and Tab. 3. Consensus was reached among the experts in the rating of the risk factors and the agreed ratings are shown Tab. 10

\subsection{Risk Assessment: Risk Priority Number (RPN) Approach analysis}

\subsubsection{Risk estimation analysis}

The value of risk of each failure mode is evaluated using Eq. 1 and the results obtained are also presented in Tab. 10 .

Tab. 10: Failure modes RPN.

\begin{tabular}{|c|c|c|c|c|c|c|}
\hline $\mathbf{S} / \mathbf{N}$ & $\begin{array}{l}\text { Failure } \\
\text { mode }\end{array}$ & $\begin{array}{c}\text { Compo- } \\
\text { nents }\end{array}$ & $\mathbf{S}$ & $\mathrm{O}$ & D & RPN \\
\hline 1 & $\begin{array}{l}\text { Failing to } \\
\text { lubricate }\end{array}$ & $\begin{array}{l}\text { Main } \\
\text { bearing }\end{array}$ & 8 & 3 & 4 & 96 \\
\hline 2 & $\begin{array}{l}\text { Hole } \\
\text { in the } \\
\text { piston } \\
\text { crown }\end{array}$ & Piston & 7 & 6 & 8 & 336 \\
\hline 3 & $\begin{array}{l}\text { Piston } \\
\text { ring } \\
\text { scuffing }\end{array}$ & Piston & 5 & 6 & 5 & 150 \\
\hline 4 & $\begin{array}{l}\text { Cracked } \\
\text { ring }\end{array}$ & Piston & 7 & 3 & 3 & 63 \\
\hline 5 & $\begin{array}{l}\text { Ring } \\
\text { /groove } \\
\text { side face } \\
\text { wear }\end{array}$ & Piston & 7 & 6 & 5 & 210 \\
\hline 6 & $\begin{array}{l}\text { Piston } \\
\text { ring } \\
\text { stuck in } \\
\text { grooves }\end{array}$ & Piston & 6 & 6 & 5 & 180 \\
\hline 7 & $\begin{array}{l}\text { Piston } \\
\text { stuck }\end{array}$ & Piston & 8 & 2 & 2 & 32 \\
\hline 8 & $\begin{array}{l}\text { Piston } \\
\text { flame } \\
\text { face ex- } \\
\text { cessive } \\
\text { wear }\end{array}$ & Piston & 8 & 7 & 7 & 392 \\
\hline 9 & $\begin{array}{l}\text { Wearing } \\
\text { out of } \\
\text { packing } \\
\text { rings }\end{array}$ & $\begin{array}{l}\text { Piston } \\
\text { rod stuff- } \\
\text { ing box }\end{array}$ & 7 & 6 & 8 & 336 \\
\hline
\end{tabular}

\begin{tabular}{|c|c|c|c|c|c|c|}
\hline 10 & $\begin{array}{l}\text { Malfunc- } \\
\text { tioning }\end{array}$ & $\begin{array}{l}\text { Piston } \\
\text { rod stuff- } \\
\text { ing box }\end{array}$ & 10 & 4 & 6 & 240 \\
\hline 11 & Cracking & $\begin{array}{c}\text { Crank- } \\
\text { shaft }\end{array}$ & 9 & 2 & 2 & 36 \\
\hline 12 & Bending & $\begin{array}{c}\text { Crank- } \\
\text { shaft }\end{array}$ & 8 & 3 & 3 & 72 \\
\hline 13 & $\begin{array}{l}\text { Journal } \\
\text { surface } \\
\text { damage }\end{array}$ & $\begin{array}{l}\text { Crank- } \\
\text { shaft }\end{array}$ & 9 & 2 & 2 & 36 \\
\hline 14 & Warping & $\begin{array}{l}\text { Cylinder } \\
\text { head }\end{array}$ & 7 & 5 & 3 & 105 \\
\hline 15 & Cracking & $\begin{array}{l}\text { Cylinder } \\
\text { head }\end{array}$ & 8 & 3 & 4 & 96 \\
\hline 16 & Breaks & $\begin{array}{l}\text { Connect- } \\
\text { ing rod }\end{array}$ & 9 & 3 & 2 & 54 \\
\hline 17 & $\begin{array}{l}\text { Cam } \\
\text { break }\end{array}$ & $\begin{array}{l}\text { Camshaft, } \\
\text { cams and } \\
\text { chain } \\
\text { drive }\end{array}$ & 8 & 3 & 2 & 48 \\
\hline 18 & $\begin{array}{l}\text { Leak } \\
\text { in the } \\
\text { cylinder } \\
\text { liner }\end{array}$ & $\begin{array}{l}\text { Cylinder } \\
\text { liner }\end{array}$ & 9 & 6 & 2 & 108 \\
\hline 19 & Worn & $\begin{array}{l}\text { Cylinder } \\
\text { liner }\end{array}$ & 5 & 5 & 4 & 100 \\
\hline 20 & $\begin{array}{l}\text { Damaged/ } \\
\text { deformed }\end{array}$ & $\begin{array}{l}\text { Cylinder } \\
\text { liner }\end{array}$ & 8 & 6 & 2 & 96 \\
\hline 21 & $\begin{array}{l}\text { External } \\
\text { leak }\end{array}$ & $\begin{array}{l}\text { Cooling } \\
\text { water } \\
\text { jacket }\end{array}$ & 7 & 3 & 4 & 84 \\
\hline 22 & $\begin{array}{l}\text { Restricted } \\
\text { passage }\end{array}$ & $\begin{array}{l}\text { Cooling } \\
\text { water } \\
\text { jacket }\end{array}$ & 7 & 3 & 5 & 105 \\
\hline 23 & Inoperable & $\begin{array}{l}\text { Crankcase } \\
\text { relief } \\
\text { valve }\end{array}$ & 7 & 2 & 9 & 126 \\
\hline
\end{tabular}

\subsubsection{Risk categorisation analysis}

Having evaluated the RPN of the different failure modes, the next step is to categorise them into three levels of risk. The indexes for the categorisation based on Tab. 4 is presented in Tab. 11. Applying Tab. 11 on the various RPN values of failure modes in Tab. 10 the results obtained are presented in Tab. 12. For example in Table 10, RPN of failure mode 1 is 96 and if it is match with RPN index 1 in Tab. 11, the risk level is "medium" because its RPN value; 96 falls within $39 \leq R P N<118$. 
Tab. 11: Risk level indexes.

\begin{tabular}{|l|l|}
\hline RPN index 1 & Level of risk \\
\hline$<39$ & Low \\
\hline $39 \leq \mathrm{RPN} \leq 118$ & Medium \\
\hline$\geq 118$ & High \\
\hline $\mathbf{R P N}$ index $\mathbf{2}$ & Level of risk \\
\hline$<78$ & Low \\
\hline $78 \leq \mathrm{RPN} \leq 196$ & Medium \\
\hline$\geq 196$ & High \\
\hline $\mathbf{R P N}$ index $\mathbf{3}$ & Level of risk \\
\hline$<157$ & Low \\
\hline $157 \leq \mathrm{RPN} \leq 274$ & Medium \\
\hline$\geq 274$ & High \\
\hline
\end{tabular}

Tab. 12: Failure modes risk level.

\begin{tabular}{|l|l|l|l|}
\hline S/N & \multicolumn{3}{|c|}{ Risk level } \\
\hline & $\begin{array}{l}\text { RPN in- } \\
\text { dex 1 } \\
\text { RPN in- } \\
\text { dex 2 }\end{array}$ & $\begin{array}{l}\text { RPN } \\
\text { index } \\
\mathbf{3}\end{array}$ \\
\hline 1 & Medium & Medium & Low \\
\hline 2 & High & High & High \\
\hline 3 & High & Medium & Low \\
\hline 4 & Medium & Low & Low \\
\hline 5 & High & High & Medium \\
\hline 6 & High & Medium & Medium \\
\hline 7 & Low & Low & Low \\
\hline
\end{tabular}

\begin{tabular}{|l|l|l|l|}
\hline 8 & High & High & High \\
\hline 9 & High & High & High \\
\hline 10 & High & High & Medium \\
\hline 11 & Low & Low & Low \\
\hline 12 & Medium & Low & Low \\
\hline 13 & Low & Low & Low \\
\hline 14 & Medium & Medium & Low \\
\hline 15 & Medium & Medium & Low \\
\hline 16 & Medium & Low & Low \\
\hline 17 & Medium & Low & Low \\
\hline 18 & Medium & Medium & Low \\
\hline 19 & Medium & Medium & Low \\
\hline 20 & Medium & Medium & Low \\
\hline 21 & Medium & Medium & Low \\
\hline 22 & Medium & Medium & Low \\
\hline 23 & High & Medium & Low \\
\hline
\end{tabular}

From Tab. 12, RPN indexes 1 and 2 produced same risk level for 15 of the failure modes representing over $65 \%$ of the total failure modes while the remaining $35 \%$ have only one step difference of risk level. The risk level produced by RPN index 3 for the 23 failure modes differs significantly from the risk level produced by RPN index 1 and 2 as RPN index 3 indicates low risk for majority of the failure modes whereas both RPN index 1 and 2 indicate either high or medium risk for almost all the 23 failure mode. The reason RPN index 3 indicate low risk for majority of the failure modes is because the index used to define low risk was set at about $40 \%$ of the maximum risk compare to about $10 \%$ and $20 \%$ of the maximum risk possible that were used to defined low risk for RPN index 1 and 
2 respectively. The indexes for defining various risk levels of equipment of any system vary from company to company and the choice generally depends on the decision maker, the risk of the overall system and the importance attached to the overall system.

Having determine the risk level of each of the failure modes of the marine diesel engine, the next step is to assign maintenance strategy to each failure mode on the basis of their respective risk level. Applying the information discussed in section II, CM, PM and CBM are selected for failure modes with low, medium and high risks respectively and the results produced are shown in Tab. 13

From Tab. 13 it is obvious, majority of the failure modes were assigned PM and CBM based on risk level generated for failure modes using RPN risk index 1 and 2 as opposed to RPN index 3 where majority of the failure modes are assign CM.

However, adequate care must be taken in the choice of RPN index for measuring risk level of failure modes because the level of risk indicated for an equipment item will determine the choice of maintenance strategy for the maintenance of the equipment item. If a wrong choice of maintenance is made, it may result to either overmaintenance or under-maintenance.

Tab. 13: Failure modes maintenance strategy.

\begin{tabular}{|l|l|l|l|}
\hline \multirow{2}{*}{ S/N } & \multicolumn{3}{|l|}{ Maintenance strategy } \\
\cline { 2 - 4 } & $\begin{array}{l}\text { RPN in- } \\
\text { dex 1 }\end{array}$ & $\begin{array}{l}\text { RPN in- } \\
\text { dex 2 }\end{array}$ & $\begin{array}{l}\text { RPN in- } \\
\text { dex 3 }\end{array}$ \\
\hline 1 & PM & PM & CM \\
\hline 2 & CBM & CBM & CBM \\
\hline 3 & CBM & PM & CM \\
\hline 4 & PM & CM & CM \\
\hline 5 & CBM & CBM & PM \\
\hline 6 & CBM & PM & PM \\
\hline
\end{tabular}

\begin{tabular}{|l|l|l|l|}
\hline 7 & $\mathrm{CM}$ & $\mathrm{CM}$ & $\mathrm{CM}$ \\
\hline 8 & $\mathrm{CBM}$ & $\mathrm{CBM}$ & $\mathrm{CBM}$ \\
\hline 9 & $\mathrm{CBM}$ & $\mathrm{CBM}$ & $\mathrm{CBM}$ \\
\hline 10 & $\mathrm{CBM}$ & $\mathrm{CBM}$ & $\mathrm{PM}$ \\
\hline 11 & $\mathrm{CM}$ & $\mathrm{CM}$ & $\mathrm{CM}$ \\
\hline 12 & $\mathrm{PM}$ & $\mathrm{CM}$ & $\mathrm{CM}$ \\
\hline 13 & $\mathrm{CM}$ & $\mathrm{CM}$ & $\mathrm{CM}$ \\
\hline 14 & $\mathrm{PM}$ & $\mathrm{PM}$ & $\mathrm{CM}$ \\
\hline 15 & $\mathrm{PM}$ & $\mathrm{PM}$ & $\mathrm{CM}$ \\
\hline 16 & $\mathrm{PM}$ & $\mathrm{CM}$ & $\mathrm{CM}$ \\
\hline 17 & $\mathrm{PM}$ & $\mathrm{CM}$ & $\mathrm{CM}$ \\
\hline 18 & $\mathrm{PM}$ & $\mathrm{PM}$ & $\mathrm{CM}$ \\
\hline 19 & $\mathrm{PM}$ & $\mathrm{PM}$ & $\mathrm{CM}$ \\
\hline 20 & $\mathrm{PM}$ & $\mathrm{PM}$ & $\mathrm{CM}$ \\
\hline 21 & $\mathrm{PM}$ & $\mathrm{PM}$ & $\mathrm{CM}$ \\
\hline 22 & $\mathrm{PM}$ & $\mathrm{PM}$ & $\mathrm{CM}$ \\
\hline 23 & $\mathrm{CBM}$ & $\mathrm{PM}$ & $\mathrm{CM}$ \\
\hline
\end{tabular}

\subsection{Risk assessment: Risk matrix based approach analysis}

\subsubsection{Risk estimation analysis}

As discussed earlier in section II, the ratings of $\mathrm{O}$ and $\mathrm{S}$ of the different failure modes of the marine diesel engine by experts is the first step in the Risk matrix based methodology. Hence, the "S" and "O" column in Table 10 is applied as input data into the risk matrix for risk of failure modes categorisation. 


\subsubsection{Risk categorisation analysis}

To categorise the risk of failure modes into three risk level; low, medium and high risks, we matched the data in "S" and "O" column in Table 10 with the risk matrix in

Tab. 8 and the results produced are shown in Tab. 14. An example, of data matching with the risk matrix had earlier been presented in section II.

Tab. 14: Failure modes risk (criticality) level and corresponding maintenance strategy.

\begin{tabular}{|l|l|l|}
\hline S/N & $\begin{array}{l}\text { Risk } \\
\text { level }\end{array}$ & $\begin{array}{l}\text { Maintenance } \\
\text { strategy }\end{array}$ \\
\hline 1 & Medium & PM \\
\hline 2 & High & CBM \\
\hline 3 & Medium & PM \\
\hline 4 & Medium & PM \\
\hline 5 & High & CBM \\
\hline 6 & Medium & PM \\
\hline 7 & Low & CM \\
\hline 8 & High & CBM \\
\hline 9 & High & CBM \\
\hline 10 & High & CBM \\
\hline 11 & Medium & PM \\
\hline 12 & Medium & PM \\
\hline 13 & Medium & PM \\
\hline 14 & High & CBM \\
\hline 15 & Medium & PM \\
\hline 16 & High & CBM \\
\hline 5 & & \\
\hline 5 & & \\
\hline 5 & &
\end{tabular}

\begin{tabular}{|l|l|l|}
\hline 17 & Medium & PM \\
\hline 18 & High & CBM \\
\hline 19 & Medium & PM \\
\hline 20 & High & CBM \\
\hline 21 & Medium & PM \\
\hline 22 & Medium & PM \\
\hline 23 & Low & CM \\
\hline
\end{tabular}

From Tab. 14 it is obvious that almost all the failure modes has either high or medium risk with the exception of "Piston stuck" and "Crankcase relief valve inoperable" that has low risk.

Applying the information discussed in section II, maintenance strategies are selected for each failure modes; with the low, medium and high risk failure modes being candidates for $\mathrm{CM}, \mathrm{PM}$ and CBM respectively and the results obtained are also presented in Tab. 14 .

\subsection{Comparison of methods}

The two techniques; RPN and Risk matrix based methods, for risk estimation/categorisation are compared using risk level and maintenance strategies generated for each failure modes by both methods as shown in Tab. 15 and Tab. 16 respectively.

Tab. 15: Comparison of methods based on failure modes risk level.

\begin{tabular}{|l|l|l|l|l|}
\hline S/N & \multicolumn{4}{|c|}{ Risk level } \\
\hline & $\begin{array}{l}\text { Risk } \\
\text { ma- } \\
\text { trix }\end{array}$ & $\begin{array}{l}\text { RPN } \\
\text { index } \\
\mathbf{1}\end{array}$ & $\begin{array}{l}\text { RPN } \\
\text { index } \\
\mathbf{2}\end{array}$ & $\begin{array}{l}\text { RPN } \\
\text { index } \\
\mathbf{3}\end{array}$ \\
\hline 1 & Medium & Medium & Medium & Low \\
\hline 2 & High & High & High & High \\
\hline
\end{tabular}




\begin{tabular}{|l|l|l|l|l|}
\hline 3 & Medium & High & Medium & Low \\
\hline 4 & Medium & Medium & Low & Low \\
\hline 5 & High & High & High & Medium \\
\hline 6 & Medium & High & Medium & Medium \\
\hline 7 & Low & Low & Low & Low \\
\hline 8 & High & High & High & High \\
\hline 9 & High & High & High & High \\
\hline 10 & High & High & High & Medium \\
\hline 11 & Medium & Low & Low & Low \\
\hline 12 & Medium & Medium & Low & Low \\
\hline 13 & Medium & Low & Low & Low \\
\hline 14 & High & Medium & Medium & Low \\
\hline 15 & Medium & Medium & Medium & Low \\
\hline 16 & High & Medium & Low & Low \\
\hline 17 & Medium & Medium & Low & Low \\
\hline 18 & High & Medium & Medium & Low \\
\hline 19 & Medium & Medium & Medium & Low \\
\hline 20 & High & Medium & Medium & Low \\
\hline 21 & Medium & Medium & Medium & Low \\
\hline 23 & Low & High & Medium & Low \\
\hline
\end{tabular}

Tab. 16: Comparison of methods based on failure modes assigned maintenance strategy

\begin{tabular}{|l|l|l|l|l|}
\hline S/N & \multicolumn{2}{|l|}{ Maintenance strategy } \\
\hline & $\begin{array}{l}\text { Risk } \\
\text { ma- } \\
\text { trix }\end{array}$ & $\begin{array}{l}\text { RPN } \\
\text { index } \\
\mathbf{1}\end{array}$ & $\begin{array}{l}\text { RPN } \\
\text { index } \\
\mathbf{2}\end{array}$ & $\begin{array}{l}\text { RPN } \\
\text { in- } \\
\text { dex } \\
\mathbf{3}\end{array}$ \\
\hline 1 & PM & PM & PM & CM \\
\hline 2 & CBM & CBM & CBM & CBM \\
\hline 3 & PM & CBM & PM & CM \\
\hline 4 & PM & PM & CM & CM \\
\hline 5 & CBM & CBM & CBM & PM \\
\hline 6 & PM & CBM & PM & PM \\
\hline 7 & CM & CM & CM & CM \\
\hline 8 & CBM & CBM & CBM & CBM \\
\hline 9 & CBM & CBM & CBM & CBM \\
\hline 10 & CBM & CBM & CBM & PM \\
\hline 11 & PM & CM & CM & CM \\
\hline 12 & PM & PM & CM & CM \\
\hline 13 & PM & CM & CM & CM \\
\hline 14 & CBM & PM & PM & CM \\
\hline 15 & PM & PM & PM & CM \\
\hline 16 & CBM & PM & CM & CM \\
\hline 17 & PM & PM & CM & CM \\
\hline 18 & CBM & PM & PM & CM \\
\hline 19 & PM & PM & PM & CM \\
\hline 20 & PM & PM & CM \\
\hline
\end{tabular}




\begin{tabular}{|l|l|l|l|l|}
\hline 21 & PM & PM & PM & CM \\
\hline 22 & PM & PM & PM & CM \\
\hline 23 & $\mathrm{CM}$ & $\mathrm{CBM}$ & $\mathrm{PM}$ & $\mathrm{CM}$ \\
\hline
\end{tabular}

From Tab. 15 it is obvious that Risk matrix and RPN based approach specifically; RPN indexes 1 and 2 produced same risk level for majority of the failure modes in which most failure modes were either assigned medium or high risk. However, the risk levels produced by RPN index 3 for the 23 failure modes differs significantly from that of Risk matrix and RPN index 1 and 2 as RPN index 3 indicates low risk for majority of the failure modes. From the above analysis different approaches for analysing failure modes risk level may or may not yield the same result, as the extent of similarity between the Risk matrix approach and the RPN method, depend on the benchmark for setting limit of risk level in the RPN method.

Tab. 16 revealed that majority of the failure modes were assigned PM and CBM based on risk level produced by Risk matrix and RPN index 1 and 2 as opposed to CM assigned to majority of failure modes based on RPN index 3 .

Special attention must be given to failure modes risk analysis because the level of risk indicated for an equipment item failure mode will determine the choice of maintenance strategy for the maintenance of the equipment item. The choice of wrong maintenance strategy may result in catastrophic failure of the system, in the case of under-maintenance or may result to unnecessary increment in maintenance budget, in the case of over-maintenance.

\section{Conclusion}

In this paper, two techniques are presented for assessment of risk of marine diesel engine. They are; the RPN and the RM based method. The methods were applied in turn to categorise risk of failure modes of marine diesel engine into three levels of risk. The first level was denoted as low risk while the second and third levels were represented as medium and high risks respectively. On the basis of the analysed risk level of failure modes maintenance strategies were assigned and for the low, medium and high risk; $\mathrm{CM}, \mathrm{PM}$ and $\mathrm{CBM}$ were assigned respectively to mitigate failure. In the application of the RPN method, three indexes were used to define risk level; RPN indexes 1, 2 and 3. RPN indexes 1 and 2 produced same risk level for over $65 \%$ of the total failure modes while the remaining $35 \%$ had only one step difference of risk level. However, the risk level produced by RPN index 3 differs significantly from that of RPN index 1 and 2 as RPN index 3 indicates low risk for majority of the failure modes whereas both RPN index 1 and 2 indicate either high or medium risk for majority of failure modes.

The three RPN indexes were only applied to reflect real life situation in which the RPN indexes for defining various risk levels of equipment have been set differently by different authors and by different companies and the choice generally depends on the risk of the overall system and the importance attach to it. The result of the three RPN indexes therefore, is an indication to maintenance practitioners to be careful in the way they set the RPN indexes, as different indexes may produce different mix of optimal maintenance strategies and if RPN index is wrongly set, it might result in either over or under maintenance. Comparing, Risk matrix and RPN approaches, the Risk matrix approach produced same risk level for majority of the failure modes with that of RPN indexes 1 and 2 in which most failure modes were either assigned medium or high risk but differs significantly from that of RPN index 3 were majority of the failure modes were assigned low risk. From the comparative analysis, it is glaring that the extent of similarity between the Risk matrix approach and the RPN based technique is a function of the benchmark for setting limit for risk level in the RPN method. Furthermore, from the analysis it is obvious, the two approaches are suitable for establishing appropriate risk level for failure mode and ultimately determining optimal maintenance strategy, the risk matrix method is recommended because the approach is simpler to analyse and implement due to the fact that it requires evaluation of only two decision criteria: 
$\mathrm{O}$ and $\mathrm{S}$ as opposed to the RPN method that requires decision maker to evaluate decision criteria; $\mathrm{D}$ in addition to $\mathrm{O}$ and $\mathrm{S}$. For future work, there is a need to develop a methodology that will enable industries and maintenance practitioners determined optimum index for their individual system failure scenario.

\section{References}

[1] Glossary of Terms used in Terotechnology, Common BSI/ISO standard, London, 1993.

[2] SEPEDA, A.L., "A risk based maintenance approach (for facilities complying with the US OSHA PSM regulation)," Journal of Loss Prevention in the Process Industries, vol. 22 no. 6 , pp. $680-684,2009$

[3] FUJIYAMA, K., S. NAGAI, Y. AKIKUNI, T. FUJIWARA, K. FURUYA, S. MATSUMOTO, K. TAKAGI, T. KAWABATA, "Risk-based inspection and maintenance systems for steam turbines," International Journal of Pressure Vessels and Piping, vol. 81 no. 10, pp. 825-835, 2004.

[4] NORDGÅRD, D.E., K. SAMDAL, "Establishing risk-based maintenance strategies for electricity distribution companies" Bris, Soares Guedes, Martorell. Editors, Reliability, risk and safety: theory and applications, pp. 377-383, 2009.

[5] NWAOHA, T.C., J. AGBAKWURU, M. O. OKWU, "Facilitating Hazard Analysis of LNG Carrier Operations via Risk Matrix Approach," International Journal of Science and Technology, vol. 5 no. 4, 2016.

[6] HAIFANG, C., Z. QUAN, G. HUAIZHI, "Risk Identification of Private Capital Participating in Government Project Based on Risk Matrix", International Conference on Management and Service Science, Wuham, China, pp.1- 4, 2009.

[7] LAZAKIS, I., "Establishing an innovative and integrated reliability and criticality based maintenance strategy for the maritime industry" $\mathrm{PhD}$ dissertation, University of Strathclyde, United Kingdom, 2011.
[8] SANTOS, J.F.D., J.M.F. CALADO, A. A. ROQUE, "Risk-based maintenance: relationship between the risk and the environment of operation," 2014; http://hdl. handle. net/10316.2/33309.

[9] JAMSHIDI, A., S. A. RAHIMI, D. AITKADI, A. RUIZ, "A comprehensive fuzzy risk-based maintenance framework for prioritization of medical devices," Applied Soft Computing, vol. 32, pp. 322-334, 2015.

[10] SCIPIONI, A., G. SACCAROLA, A. CENTAZZO, F. ARENA, "FMEA methodology design, implementation and integration with HACCP system in a food company," Food Control, vol. 13, pp. 495-501, 2002

[11] EMOVON, I., "Inspection interval determination for mechanical/service systems using an integrated PROMETHEE method and delay time model," Journal of Mechanical Engineering and Technology, vol. 8, no. 1, pp. 13-29, 2016.

[12] CHIN, K.-S., Y.-M. WANG, G. KA KWAI POON, J.-B. YANG, "Failure mode and effects analysis using a group-based evidential reasoning approach", Computers $\& O P$ erations Research, vol. 36 no. 6, pp. 17681779, 2009.

[13] CICEK, K., M. CELIK, M. "Application of failure modes and effects analysis to main engine crankcase explosion failure on-board ship," Safety Science, vol. 51, no. 1, pp. 610,2013

[14] XU, K., L. C. TANG, M. XIE, S. L. HO, M. L. ZHU, "Fuzzy assessment of FMEA for engine systems," Reliability Engineering \& System Safety, vol. 75 , no. 1, pp. 17-29, 2002

[15] CHIN, K.S., Y. M. WANG, G. K. K. POON, J. B. YANG, "Failure mode and effects analysis by data envelopment analysis," Decision Support Systems, vol. 48, no. 1, pp.246-256, 2009.

[16] KHAN, F.I., M. M. HADDARA, "Riskbased maintenance (RBM): a quantitative approach for maintenance/inspection scheduling and planning," Journal of loss 
prevention in the process industries, vol. 16 no. 6, pp. 561-573, 2003.

[17] HAMEED, A., F. KHAN, "A framework to estimate the risk-based shutdown interval for a processing plant," Journal of Loss Prevention in the Process Industries, vol. 32, pp. 18-29, 2014.

[18] EMOVON, I., R. A. NORMAN, A. J. MURPHY, "A new tool for prioritising the risk of failure modes for marine machinery systems," In Proceedings of the 33rd International Conference on Ocean, Offshore and Arctic Engineering, San-Francisco, pp. 1-10, 2014

\section{About Authors}

I. Emovon is a senior lecturer in Mechanical Engineering Department of the Federal University of Petroleum Resources, Effurun, Nigeria.
He obtained his PhD degree in Maritime Technology from Newcastle University, Newcastle Upon Tyne, United Kingdom. His research interest are; engineering system maintenance modelling and optimisation, risk analysis and multi-criteria decision making in industrial system environment. The author has published several papers in reputable international Journals such Applied Energy, Applied Ocean Research and Ocean Engineering and he is a reviewer to some of these Journals.

M. Okwu is a lecturer in the Department of Mechanical Engineering, Federal University of Petroleum Resources, Effurun, Nigeria. He obtained his $\mathrm{PhD}$ degree in Mechanical Engineering from Federal University of Technology, Owerri, Nigeria. His research interest are in the area of Complex System Modelling, Supply Chain Design, Industrial Safety and Robotics. The author has published papers in both national and international reputable Journals.

"This is an Open Access article distributed under the terms of the Creative Commons Attribution License, which permits unrestricted use, distribution, and reproduction in any medium, provided the original work is properly cited (CC BY 4.0)." 